\title{
Muséologies
}

Les cahiers d'études supérieures

\section{Restitution of Art and Antiquities: What are the implications of Holocaust restitution for museums that collect antiquities?}

\section{John Impert}

Volume 2, numéro 2, avril 2008

URI : https://id.erudit.org/iderudit/1033586ar

DOI : https://doi.org/10.7202/1033586ar

Aller au sommaire du numéro

Éditeur(s)

Association Québécoise de Promotion des Recherches Étudiantes en

Muséologie (AQPREM)

ISSN

1718-5181 (imprimé)

1929-7815 (numérique)

Découvrir la revue

Citer cet article

Impert, J. (2008). Restitution of Art and Antiquities: What are the implications of Holocaust restitution for museums that collect antiquities? Muséologies, 2(2), 14-29. https://doi.org/10.7202/1033586ar
Résumé de l'article

John Impert cherche à faire un peu de lumière sur les dissensions qui se sont crées entre les défenseurs de patrimoine national, et les grands musées universels qui tentent, tant bien que mal de conserver des oeuvres saisies illégalement au cours du troisième Reich. Pour démontrer son propos, il a choisi de se concentrer sur les aléas juridiques impliquant héritiers et musées, dans des cas de restitutions éminentes d'oeuvres spoliées au cours de la deuxième guerre mondiale, en Autriche. 
John Impert cherche à faire un peu de lumière sur les dissensions qui se sont crées entre les défenseurs de patrimoine national, et les grands musées universels qui tentent, tant bien que mal de conserver des œuvres saisies illégalement au cours du troisième Reich. Pour démontrer son propos, il a choisi de se concentrer sur les aléas juridiques impliquant héritiers et musées, dans des cas de restitutions éminentes d'œuvres spoliées au cours de la deuxième guerre mondiale, en Autriche.

JOHN IMPERT EST CANDIDAT À LA MAITTRISE EN L'HISTOIRE DE L'ART À L'UNIVERSITÉ DE WASHINGTON. IL DÉTIENT UN B.A. DE L'UNIVERSITÉ YALE, UN CERTIFICAT D'ÉTUDES EN SCIENCES POLITIQUES DE LINSTITUT D'ÉTUDES POLITIQUES À PARIS, ET UN DIPLOOME EN JURISPRUDENCE DE LA FACULTÉ DE DROIT DE HARVARD. IL A VÉCU ET PRATIQUÉ LE DROIT À BRUXELLES ET À PARIS, OÙ IL ÉTAIT MEMBRE DU BARREAU DE PARIS. JOHN IMPERT A PUBLIÉ DE NOMBREUX ARTICLES SUR DES QUESTIONS DE DROIT ET EST AUSSI LAUTEUR D'UN ARTICLE PORTANT SUR LE TABLEAU LE CHAHUT DE SEURAT À PARAITRE DANS LA PUBLICATION NEW YORKAISE ART CRITICISM. [johnimpert@yahoo.com] 
[1]

The other categories of Holocaust-related claims are so-called dormant bank accounts, slave labour for German industry during World War II, and pre-World War II life insurance policies. Along with art, the category that has garnered the most attention in the press has been dormant bank accounts, principally in Switzerland and France.

A comprehensive account of restitution activities, with a focus on the involvement of US courts, is provided by Michael J. BAZYLER (Holocaust Justice. New York: New York University Press, 2003). Modest successes were achieved in restitution of Swiss bank accounts belonging to Holocaust victims, a broad negotiated settlement resulted in some payments to former slave labourers

in Germany and Austria, while no additional significant payments were made on life insurance policies that may have been issued to Jews who died in the Holocaust.

Rebecca MEAD provides an overview of antiquities restitution by the Metropolitan Museum of New York ( Den of Antiquity: The Met Defends its

Treasures". The New Yorker, April 9, 2007, p. 52-61).
The restitution to heirs of victims of the Holocaust of art objects taken by the Nazis has received considerable press attention, most dramatically Maria Altmann's recovery in 2007 of five Klimts. Lost art is but one of several categories of claims that have benefited from a renewed concern about justice for Holocaust victims and their heirs. ${ }^{[1]}$ Concurrently, restitution claims have been made by Italy, Greece, and other countries for objects that may have been illegally excavated and exported. ${ }^{[2]}$ Academic commentators and journalists have tended to applaud all such restitution claims, viewing not only Holocaust heirs as victims, but also treating as victims the countries that were the source of illegally excavated antiquities. Criticism has been directed in turn at those who seized or otherwise acquired the art objects that belonged to Jewish owners and at those who purchased antiquities.

Important collectors like the Metropolitan Museum of New York are involved in both Holocaust and antiquities cases, and "national patrimony" legislation, i.e., laws that seek to keep art and antiquities within a nation's borders, can be decisive in the disposition of both categories of cases. Yet the academic community and journalists view national patrimony legislation differently in the two sorts of cases. Although national patrimony laws and the national cultural property doctrine that inform them are essential to the success of a claim for the restitution of antiquities, the same laws and doctrine are criticized as unjustifiable impediments in many Holocaust cases.

This essay will address this apparent contradiction through an analysis of restitution to heirs of Holocaust victims of art objects that were seized or otherwise lost in Austria during the Nazi period from 1938-1945, or for which export was refused after World War II because of Austria's national cultural heritage policies. Although this paper concentrates on Austria, the same issues have arisen in nearly all other European countries governed or occupied by the Nazis. The paper will describe the historical and legal context in Austria and then take up two case studies of Holocaust restitution that garnered extensive press attention, Dead Town III by Egon Schiele (1890-1918), which became subject to a restitution claim while on loan from an Austrian museum to the Museum of Modern Art (MoMA) in 1997, and Portrait of Adele Bloch Bauer I and four other paintings 
by Gustav Klimt (1862-1918), formerly in the Austrian State Belvedere Museum in Vienna, which were recently recovered and sold by the Altmann claimants of California. It will then describe the national cultural property doctrine, which asserts that nation states should have the ultimate moral right to determine what cultural property should remain within their borders. It will analyze how this doctrine conflicts with the results of the Holocaust art restitution campaign, and it will argue that the discourse of Holocaust restitution raises major challenges to today's prevailing policies of cultural nationalism. ${ }^{[3]}$

\section{The Holocaust in Austria}

Events that led directly to the Holocaust, the killing of approximately six million European Jews, began with Hitler's selection in 1933 as Chancellor of Germany. In 1938, Germany brought pressure upon Austria to agree to be incorporated within the German Reich, the Anschluss. As a result, German law, notably anti-Semitic legislation, became applicable in Austria, and property including art belonging to Austrian Jews was seized. Of over 220,000 Jews in pre-Anschluss Austria, 65,500 died in concentration and death camps, 5700 survived the war in Austria, while the remainder emigrated from Austria in 1938 and 1939 and generally survived the war abroad. ${ }^{[4]}$ Emigrants, however, were often unable to take their art objects when they departed from Austria. Thus, art restitution claims involve those who survived the Holocaust as well as those who perished.

Austria has tended to proclaim itself a victim of Hitler rather than his accomplice on the basis of the Moscow Declaration of 1943 by the leaders of the Allies, the United States, Great Britain, and the Soviet Union, which referred to Austria as the country that was the "first victim" of the Nazis. ${ }^{[6]}$ Although the Declaration was intended as wartime propaganda to incite the Austrians to resist German domination, after the war Austrian politicians tended to cite it as "plenary exculpation" for the peoples of Austria's participation in wartime activities, including the Holocaust, on Germany's side. ${ }^{[6]}$ It should be noted that no European nation that was conquered by Germany can escape criticism for its wartime behaviour. Denmark, for example, is often cited approvingly for having saved almost all of its 7000 Jews, who were ferried clandestinely to neutral Sweden. Denmark, however, at the outset of the war decided not to resist the German invasion and offered to govern itself under German administrative supervision, allowing Germany to dispatch only a token number of troops. Denmark thereby facilitated Germany's conquest of Norway, and Denmark's lack of resistance and

\section{[3]}

The author is grateful to Professor Patricia Failing of the History of Art Department of the University of Washington for her close reading and trenchant comments on a draft of this paper.

[4]

DONAHUE, William C.

«'Bless My Homeland Forever': Teaching Austria and the Holocaust ». Teaching German, vol. 29, no. 2, 1996, p. 191.

[5]

PICK, Hella.

Guilty Victim: Austria from the Holocaust to Haider. London: I.B. Tauris, 2000, p. 17.

[6]

DONAHUE, op. cit, p. 189. 
[7]

DEAR, I.C.B. The Oxford Companion to World War II. New York: Oxford University Press, 1995, p. 293-294.

[8]

Emphasis on the Holocaust is not surprising given that Germany's attempt to exterminate European Jewry ranks as one of the greatest crimes of the twentieth century. A current example of assessing the behaviour of European nations in their treatment of Jews focuses on areas not under direct German occupation, i.e., Vichy, France, Slovakia, Hungary, Bulgaria, and Romania. Behaviour of the authorities in all of these areas was found to have been deplorable. (PAXTON, Robert O. "Letters". New York Review of Books, January 11, 2007, p. 66.)

[9]

RIDING, Alan,

«Foot Dragging on the Return of Art Stolen by the Nazis". <nytimes.com>, May 18, 2004, p. 2.

[10]

HENRY, Marilyn.

"Restitution: Broken Promises". ArtNews, March 2005, p. 102.

The US Army still holds art from the Nazi period, in particular 6000 objects that the army seized in 1945-1946 for fear

that they glorified Nazism. (DUBOFF, Leonard D. and Sally H. CAPLAN. The Deskbook of Art Law. Dobbs Ferry, NY: Oceana Publications, 1998, p. D-21.)

[11]

BAZYLER,

op. cit., p. 204.

In a detailed study of seized art objects using the archives of the Vichy government, it appears that, after World War II, 60\% were restored (or the original owner agreed that good title had passed to a third party), while the fate of $40 \%$ of the objects could not be determined. (Le Pillage de l'art en France pendant l'OCcupation et la situation des 2000 œuvres confiées aux Musées nationaux. Paris, 2000, p. 153.) generally cooperative behaviour permitted Germany to use troops elsewhere for most of the war. ${ }^{[7]}$

In recent years, treatment of Jews has tended to dominate assessments of countries' behaviour during World War II in Europe. ${ }^{[8]}$ Countries like Denmark escape criticism for extensive collaboration so long as they made an effort to protect their Jewish populations. In contrast, peoples that implemented anti-Semitic legislation with enthusiasm, like the French and the Austrians, are singled out for special opprobrium. Under such circumstances, Austria is no longer able to shield itself from criticism on the "first victim" theory.

\section{Looted and Lost Art}

The Commission for Looted Art in Europe, a private organization based in London, proclaims that "[ $\mathrm{t}]$ here are thousands of [Nazi] looted works of art in public collections throughout Europe [today]." ${ }^{[9]}$ In fact, there are no accurate figures on the amount of lost art still in public or private collections, and these large numbers do not seem credible, at least in terms of paintings. Immediately after World War II, massive numbers of art works were returned to their owners. The United States Army restored 3.68 million pieces of art to their countries of origin, who were each responsible for locating their owners. ${ }^{[101}$ For example, 60,000 works of art were returned to France; of this total, 45,000 were restored to their Jewish owners. ${ }^{[11]}$ Nevertheless, an unknown number of unclaimed works of art from Jewish owners ended up in public collections in Europe and elsewhere.

Over the last ten years, the issue of restitution has come to the fore as a result of renewed historical attention to the Holocaust, heightened interest in the value of art as new records are regularly set for formerly neglected artists, and the support of individuals like Ronald Lauder, philanthropist and former US Ambassador to Austria. ${ }^{[12]}$ Results of this new attention to Holocaust restitution are mixed. As of 2004, Austria had reviewed its national collections and resolved 92 new restitution cases involving 2659 "works of art," but most were individual coins, books, and pieces of porcelain. In the Netherlands, from the creation of a Restitution Committee in 2002 until 2004, nine requests for restitution were granted and three were denied. Among works of art in Germany's 6000 museums, five objects have been returned from federal museums and fifteen from regional museums based on claims received in recent years. ${ }^{[13]}$ As concerns the United States, Philippe de Montebello, the director of the Metropolitan Museum in New York, 
testified in 1998 that only two claims for looted art had been lodged with the Metropolitan Museum from 1945 to 1998 , one by Belgium for a $15^{\text {th }}$-century painting that the Met had purchased at auction, and a second by a non-Jew for a Monet claimed to have been looted by the Russians after the war and that had been given to the Met in $1994 .{ }^{[14]}$ It would thus appear that most of the art in public collections in Europe and the United States that can readily be identified to have been looted by the Nazis, and for which a legitimate claimant has come forward, have already been returned. ${ }^{[15]}$

Restitution claims are often difficult to settle because of the specific facts of each case. There is no doubt that anti-Semitism under Hitler forced many German and Austrian Jews to dispose of their art collections and emigrate. Yet, in Berlin itself, Jewish-owned auction houses continued to operate up to 1939, and several world records for prices of artists were set during the Nazi regime. ${ }^{[16]}$ At one extreme, if a painting had been seized by the Nazis without compensation and had been placed in a German or Austrian public museum, there would be little reason to object today to a claim by the direct heir of the original Jewish owner. At the other extreme, would it be equitable for a distant heir (perhaps related only by marriage) of a Jewish seller, who fully realized the market value of his or her art during the 1930's, to now recover the work of art from an innocent purchaser who bought it much later at fair market value? Put another way, while it is indisputable that the Jewish seller was a tragic victim even if he or she survived the war, the owner of the work of art today was virtually never involved in having wronged the Jewish seller initially. An example frequently commented upon that reflects these circumstances involves Ismar Littmann, a major Jewish art collector who died in 1934. During the late 1930's, his widow sold much of his art collection at auction in Berlin through Max Perl, a noted Jewish art dealer. One German expressionist painting by Emil Nolde was purchased by a German Jewish collector, apparently at fair market value; the collector survived the war and sold the painting in 1956 to a German museum, again at fair market value. Ruth Haller, Littmann's only surviving child, claimed ownership of the painting in 1999 on the ground that her mother would not have sold it but for the Nazis' growing persecution of Jews. ${ }^{[17]}$ The most equitable resolution of this claim is not obvious. ${ }^{\text {[18] }}$ Additional complications include the fact that civil law rules applicable on the European continent typically protect an innocent purchaser, statutes of limitation in nearly all European countries on Holocaust restitution claims have run (although some countries like Austria have enacted legislation enabling new claims), heirs have sometimes not pursued their claims on a timely basis (conversely, public information that would have facilitated such claims has often been unavailable), and competing claims among heirs sometimes emerge, which the possessor of the work of art is not in a position to resolve.
[12]

BOHLEN, Celestine.

"Lauder's Mix of Restitution and Collec-ting . <nytimes. com>, February 27, 2003, p. $1-4$. Since 2004,45 additional restitution claims have been submitted in the Netherlands, with up to 20 further claims expected before the deadline of April 4, 2007. The current state of restitution claims in the United Kingdom, Hungary, the Netherlands, France, and Austria are described in ArtNews (January 1, 2007, p. 102 et seq.).

[13]

Data on all three nations from RIDING (op. cit, p. 2). In February 2006, the Dutch government agreed to return 202 paintings to the heirs of Jacques Goudstikker, a Jewish art dealer who had fled Amsterdam in 1940. The paintings had been placed in Dutch national collections in 1952 after a settlement on ownership was reached with Goudstikker's widow. The settlement was disavowed after 2002 by the wife of Goudstikker's deceased son, who filed the claim that resulted in the return of these paintings to her. (ROTTENBERG, Hella. «Repairing Injustice . ArtNews, January, 2007, p. 104.) Hella Rottenberg notes that the decision in such cases turns on whether a sale of art before World War II by a Jewish owner was "involuntary," noting that many such sales were "normal." The resolution of the Goudstikker claim thus resembles the Altmann arbitration concerning the Klimts discussed in detail in this essay. In February, 2007, the Goudstikker heirs consigned 170 of the paintings to Christie's for sale. (VOGEL, Carol. «Recovered Artworks Heading to Auction * <nytimes. com>, February 21, 2007, p. 1-3.) 
House Committee on Banking \& Financial Services. The Restitution of Art Objects Seized by the Nazis. $105^{\text {th }}$ Cong., 2nd sess., 1998, p. 8.

[15]

Austria has now created an online database of thousands of objects that may have been expropriated from Jewish and other owners from 1938 to 1945. Descriptions are accompanied by a digital photograph. ( Holocaust Survivors Look for Stolen Art". <nytimes.com>, October 24, 2006.) The

Ame-rican Association of Museums (AAM) offers a NaziEra Provenance Internet Portal (<www.nepip.org >) providing a searchable registry of objects in US museum collections that were created before 1946 and changed ownership in Europe during 1933-1945. AAM also issued guidelines on the Unlaw-

ful Appropriation of Objects during the Nazi Era in November 1999, amended April 2001, for acquisitions and loans, which set forth standards of due diligence for its members.

[16]

RAUE, Peter.

"Stolen Jewish Cultural Assets under Legal Examination *. In. HOFFMAN, Barbara T. (ed.). Art and Cultural Heritage. Cambridge: Cambridge University Press, 2006, p. 185-190.

[ $\pi]$

See HOFFMAN, op. cit, p. 185; and HENRY, op. cit, p. 100.

[18]

From news reports, it appears that the painting was not restored to Haller.

[19]

See NATTER, Tobias.

«Egon Schiele and the Neulengbach Affair ». In. PRICE, Renée (ed.). Egon Schiele, The

Ronald S. Lauder and Serge Sabarsky Collections. Munich: Prestel Verlag, 2005.

\section{Case Study: Schiele's Dead Town III}

Egon Schiele is today one of the most sought after of the German and Austrian expressionists. He was a controversial figure during his own brief lifetime, having been jailed on suspicion of pedophilia, and having been known principally as a sort of pornographer. ${ }^{[19]}$ Schiele died in 1918, and his artistic profile had fallen so far as of 1937 that the Nazis neglected to classify him among the group of banned "degenerate" artists. ${ }^{[20]}$ Rudolph Leopold, a Vienna ophthalmologist, began buying Schiele and other expressionists as a young doctor after World War II at a time when few were collecting them, and his collection is now housed in the quasi-public Leopold Museum in Austria. ${ }^{[211}$ Dead Town III is a pencil, gouache and oil on wood, $15 \times 12$ " (1911), depicting the crooked narrow streets and jumbled houses of the Krumau Old Town from a steep perspective. When exhibited in Paris in 2005-2006, it was said to demonstrate - in stereotypical language typical of exhibition catalogues - "how strongly Schiele's art is anchored in Symbolism but is led out from this starting point to astoundingly original Expressionism." [22] In a more thoughtful vein, Kimberly A. Smith has argued that Schiele's landscapes address "the compelling problems of national identity [...] and the typically modern nostalgia for a lost past." ${ }^{2331}$ Smith's emphasis on issues of national identity is noteworthy, as it raises the issue of whether or not such paintings are key constituents of a nation's "patrimony." Although Schiele's works did not command high prices in the art market until the 1970's, Austrian art historians recognized their importance for Austria's cultural heritage at least from the end of World War II. The Austrian state declined to issue export permits for Schieles in several cases in order to preserve Austria's cultural property. In the words of Sophie Lillie, referring to restitution and export from Austria of Schieles by their Jewish owners, "the [...] most pernicious obstacles to restitution [...] were Austrian export regulations, enforced rigidly by the Austrian state in the aftermath of World War II to secure objects regarded as part of the country's national heritage." [24] She considers such "restrictive" policies to be "pernicious" because they allowed Jewish owners or their heirs to possess and enjoy their paintings only in Austria and prevented them from exporting the paintings to whatever country had become their home after emigration.

In 1997, the Museum of Modern Art in New York received letters from two families, each of whom claimed to be the rightful owner of different paintings by Egon Schiele on exhibition at the MoMA under a loan from the Leopold Museum, Dead Town III and Portrait of Wally. ${ }^{251}$ Both paintings were eventually seized by American authorities pending resolution of the claims. Dead Town III was returned to the Leopold Museum in 1999, but Portrait of Wally still languishes in legal limbo in New York, held for safekeeping by 
MoMA. ${ }^{[26]}$ In the case of Dead Town III, a relative of its prewar owner, Fritz Grunbaum, who had perished childless in a death camp, was declared sole heir by an Austrian court after the war. She recovered the painting from the Austrian government and sold it to a gallery in Switzerland in the 1950's (in this case, there were apparently no export restrictions); after some intervening sales, it was purchased by Dr. Leopold. The 1997 claim against MoMA that led to seizure of the work by US authorities was made by a woman whose late husband was a cousin of Grunbaum, and who argued that her husband should have been entitled to the painting rather the earlier claimant. As Glenn Lowry, head of MoMA, remarked, "no museum can resolve these claims [between competing family members]." ${ }^{27]}$ As for the Leopold Museum that lent the paintings to MoMA, as of 2003 it had spent over $\$ 1$ million in legal fees to American lawyers in asserting what it believes are its legitimate ownership rights. ${ }^{[28]}$

\section{Case Study: Klimt's Adele Bloch-Bauer I}

Gustav Klimt, who died in 1918, the same year as Egon Schiele, had a much longer career as an artist and as a teacher. Well known as an academic painter earlier in his life, he became a founding member of the Austrian secession in the late $19^{\text {th }}$ century and a leading Austrian modernist artist. Like Schiele, Klimt's reputation has had its ups and downs, but the latter's were even more extreme. Herbert Read, in his Concise History of Modern Painting (1959, enlarged and revised 1968), does not mention Klimt at all, although Schiele merits a colour reproduction. In one generation, from 1968 to 2006, Klimt's international reputation has progressed from neglect among francophile art historians like Read to that of the most expensive artist in history, when Ronald Lauder recently purchased Adele Bloch-Bauer I for \$135 million. ${ }^{[29]}$

Adele Bloch-Bauer I, oil, silver, and gold on canvas, 55 X 55" (1907), is Klimt's most famous portrait, typifying his so-called "golden style." His portraits "remained consistent with the 'male gaze' directed at 'woman", but were innovative in their mosaic-like decorative effects. ${ }^{\text {[30] }}$ Since World War II, Adele Bloch-Bauer I has been the most prized possession of the Austrian State Belvedere Museum in Vienna, where it was featured both on the cover of the museum's catalogue of its collection, and in an exhibition in Vienna entitled Klimt's Women (admired by the author of this paper in October 2000). Gerbert Frodl, director of the museum, notes that:

\section{[20]}

See PICK,

op. cit, p. 177.

[21]

Ronald LAUDER,

the most prominent American

Schiele collector, says of Dr.

Leopold that he "is the greatest collector and most knowled-

geable expert on Schiele."

("Discovering Schiele».

In. PRICE, op. cit, p. 38.

\section{[22]}

SMOLA, Franz. Vienna 1900.

Grand Palais, Paris exhibition

catalogue, 2005, p. 188.

[23]

SMITH, Kimberly A.

Between Ruin and Renewal:

Egon Schiele's Landscapes.

New Haven: Yale University

Press 2004, p. 7.

[24]

LILLIE, Sophie.

"A Legacy For-lorn *.

In. PRICE, op. cit, p. 128.

[25]

Statement of Glenn D. LOWRY,

House Committee, op. cit, p. 12.

[26]

The claim of ownership to

Portrait of Wally was made by

the family of Henri Bondi, who

asserted that the painting belon-

ged to his aunt, a Jewish art

dealer, who fled Vienna in 1938

According to the family, she had

been forced by the circumstan-

ces of the German takeover of

Austria to sell at an unfairly low

price and had been unable to

take the funds with her when

she immigrated to England. (This

represents a variation of the

Littmann case described in the

text above.) (CNN, September

21, 1999, <http://www.cnn.

com/US/9909/21/looted.

art $>$.) After the Leopold Museum

prevailed in a lawsuit before

the New York State Court

of Appeals, the Bondi family

commenced litigation in federal

district court in New York that

remains unresolved. 
op. cit., p. 12. For an extensive account of what happened to early Austrian collections of Schiele's works under the

Nazis and during the postWorld War II restitution process see LILLIE, "A Legacy Forlorn", op. cit, p. 111-139.

[28]

EAKIN, Hugh.

«Austria: Justice Delayed ». ArtNews, June 2003 ,

p. 109.

[29]

Ronald Lauder's record purchase price has already been shattered by payment of

$\$ 140$ million for a Pollock. In any event, one can question whether R. Lauder's payment

truly represented a "market" price, as it occurred in a private transaction with Maria Altmann. As Lauder is already the foremost American collector of modernist Austrian painting, to the extent his payment for Adele Bloch-Bauer / has raised the floor for prices of such paintings, he is the prime beneficiary in terms of the value of Austrian modernist works that he and the museum he created already own.

[30]

Tobias NATTER and Max HOLLEIN (eds.). The Naked Truth: Klimt, Schiele, Kokushka and other Scandals. Exhibition catalogue, Munich, 2005, p. 38.

[31]

Tobias NATTER and Gerbert FRODL. Klimt's Women. New Haven: Yale University Press, 2000, p. 7-9.

[32]

BAZYLER, op. cit., p. 241. even today, a full century later, Vienna with its Ringstrasse, its Secession building, and its countless reminders of the Klimt era [...] provides the perfect setting for [Klimt's Women] exhibition [...] far more [...] than any other venue could [...] Vienna's special circumstances produced the phenomena in painting that are only incompletely and cursorily described as "Vienna around 1900" or "secessionism." The situation was dominated by Klimt as the outstanding artistic personality. ${ }^{[311}$

The themes and vocabulary stressing the importance of the secession period in Austria's cultural heritage, and Klimt's predominant role, are evident.

Adele and her husband Ferdinand Bloch-Bauer were prominent Austrian Jews. When Adele died childless in 1925, her will expressed the desire that her Klimt paintings (two portraits and four landscapes) be given to the Austrian National Gallery after her husband's death. ${ }^{.22}$ Subsequent to the Anschluss in 1938, Ferdinand fled to Switzerland, while his niece Maria and her husband emigrated first to England and later to the United States. Ferdinand's art collection was seized and dispersed under the Nazis, some paintings going to museums and others taken by individuals. Ferdinand died in 1945, but his will did not bequeath any objects to Austrian museums, and Maria Altmann ultimately became his sole heir.

After the war, Austrian law made all "Aryanizations" null and void, and the Altmanns recovered ownership of the Klimts, except for one landscape, which Ferdinand had donated to the Belvedere Museum before the Anschluss. However, Austrian law also prohibited the export of art works deemed important to Austria's cultural heritage. ${ }^{\left[{ }^{33]}\right.}$ Even if Klimt's reputation had faded on the international scene, within Austria his importance in art and cultural history was well recognized. As characterized by an American judge involved in recent litigation over the Klimts, "it was [Austrian government] policy to use the export license law to force Jews who sought export of artworks to trade artworks for export permits on other works." ${ }^{[3]}$ In 1948, an Austrian lawyer retained by the Altmanns negotiated a settlement with the Austrian government under which the Altmanns could export most other works of art owned by the family in return for the donation of the five Klimts to the Belvedere Museum. Subsequently, in the midst of the Schiele controversy at the MoMA, Maria Altmann made a claim under Austria's new 1998 restitution law for return of the Klimts and other art works, citing the coercive nature of the 1948 settlement. The Austrian Advisory Board created under the new legislation recommended that sixteen Klimt drawings and nineteen pieces of porcelain worth more than $\$ 1$ million be restored to Altmann, but declined to return the Klimt paintings based on the terms of Adele's will, specifically her desire that the paintings go to an Austrian public collection. ${ }^{(35)}$ Altmann then brought a lawsuit against Austria in the 
United States. ${ }^{[36]}$ After the lawsuit survived several motions to dismiss by Austria, and following trial court and appellate decisions allowing the case to proceed, Altmann and Austria agreed to submit the dispute to binding arbitration in Austria. In March, 2006, the Austrian arbitration board decided in favour of Altmann, then 90 years old, and the paintings, "considered Austrian national treasures," were returned to her. ${ }^{\text {[3] }}$

In September, 2006, Adele Bloch-Bauer I was sold to Ronald Lauder for \$135 million as noted earlier and, in November 2006, the other Klimts were sold at auction at Sotheby's for $\$ 87.9$ million for the second portrait, and $\$ 40.3$ million, \$33 million, and \$31 million for the three landscapes. As Ms. Altmann was childless, the ultimate beneficiaries are presumed to be her deceased husband's American nieces and nephews. Adele Bloch-Bauer I is now visible to the American public and foreign visitors at Lauder's Neue Galerie in New York, while the other Klimts were purchased by private collectors. ${ }^{[3]}$

\section{National Cultural Property}

Holocaust restitution causes us to recall dramatic and horrific scenes from the Nazi period. Ronald Lauder emphasized that they are "not just a matter of returning property. These works are often families' only connection remaining to loved ones killed in the Holocaust." He stressed the moral imperative of "returning these cultural objects to their rightful owners." ${ }^{[39]}$ Taking a more cynical view, Judge Jed S. Rakoff of the United States District Court of Manhattan, in his recent dismissal of a Holocaust restitution lawsuit over a Picasso, noted that "one may suspect that this is just a fight about money." [40] Putting aside personal opinions of fairness, and thinking only of end results in quasi-accounting terms of "symbolic capital," what does the Klimt restitution decision mean for these five works of art that Ronald Lauder would agree are Austrian cultural treasures? Austria's "treasure account" has now had five treasures removed and placed in America's "treasure account." Largely if not solely within America, many hundreds of millions of dollars have changed hands, as between the buyers of the Klimts and Maria Altmann, possibly resulting in no net change in America's "cash account" (America's lawyers having of course shared generously in the proceeds). Austria's desire to preserve its national cultural heritage has been frustrated; the Belvedere Museum's director spoke of "a harsh blow to Austrian culture." ${ }^{[41]}$ At the very moment American museums like the Metropolitan, the Boston Museum of Fine Arts, and the Getty are returning works of art made in ancient Greece to

\section{[33]}

Austria's Ausfuhrverbotsgesetz, or Export Control Law, enacted in 1918 and amended in 1923 enabled the Austrian government to determine what works of art could be exported. (RATHKOLB, Oliver. presentation at the German Studies Association Conference, September 26 , 1997, Washington, DC; BISCHOF, Günter and Anton PELINKA. Contemporary Austrian Studies. Rutgers University, vol. 7, 1999. [34]

Quoted in BAZYLER,

op. cit, p. 242.

[35]

GREENHOUSE, Linda.

" Justices Take Case on NaziLooted Art». <nytimes.com>, October 1, 2003.

[36]

BAZYLER,

op. cit., p. 242-249.

[37]

HENRY, Marilyn.

*International News * ArtNews, March 2006, p. 78.

[38]

vOGEL, Carol.

«Klimts Spark Bidding».

New York Times, sec. A,

November 9, 2006

[39]

LAUDER, Ronald.

"The Cultural Spoils of War".

$<$ nytimes.com>, December 26, 2002, p. 2.

[40]

HARTOCOLLIS

Anemonia. "Judge Refuses to Halt the Auction of a Picasso". New York Times, sec. A November 8, 2006.

[41]

LILLIE, Sophie.

«International News *. ArtNews, March 2006, p. 80. Lillie provides an extensive account of art lost by Austrian Jewish families in Was einmal war: Handbuch der enteigneten Kunstsammlungen Wiens Mhat Once Was: a Handbook of Vienna's Plundered Art Collections]. Vienna: Czernin Verlag, 2003. 
modern Italy, and as the British Museum continues to resist Greek pressure to repatriate the Elgin marbles, the Neue Galerie has acquired a work of art that would seem to have a stronger tie to Austria's living cultural heritage than ancient Greek vases and statuary resident in America have to Italy's distant past as the site of former Greek colonies. ${ }^{[42]}$

[42]

The status of Italy's agreements with the Met and Boston, which involve the repatriation of illegally excavated and exported antiquities in return for long-term loans, is described by KENNEDY, Randall. "Italy Lends Antiquities to 2 Museums". New York Times, November 29, 2006, p. B-5.

[43]

MERRYMAN, John $\mathrm{H}$. and Albert E. ELSEN (eds.). "A Brief Intellectual History". In. Law, Ethics and the Visual Arts. London: Kluwer, 1998, p. 71.

[44]

Ibidem.

[45]

Ibidem.

[46]

BATOR, Paul M.

The International Trade in Art. Chicago: University of Chicago Press, 1982, p. 28.

[47]

LYONS, Claire L.

*Objects and Identities: Claiming and Reclaiming the Past . In. BARKAN, Elazar and - Ronald BUSH (eds.). Claiming the Stones, Naming the Bones. Los Angeles: Getty Research Institute, 2004, p. 116-129.

[48]

WARREN, Karen J. "A Philosophical Perspective on the Ethics and Resolution of Cultural Property Issues". In. MESSENGER, Phyllis (ed.).

The Ethics of Collecting Cultural Property. Albuquerque: University of New Mexico Press, 1999, p. 8.
Most nations today claim authority over works of art located within their boundaries on the ground that such objects are critical to the understanding and preservation of their national cultural heritage and, by extension, their national identity as a people. The principal policy positions on national cultural property, or cultural nationalism, have been summarized by John H. Merryman as follows: cultural nationalism means that "[c]ultural objects belong in the territory of the nation of origin and, if they stray from it, should be returned." " ${ }^{{ }_{43} 3}$ A competing doctrine involves cultural internationalism and tends to be promoted by "market nations" like Great Britain and the United States and the international art and antiquities trade. "It emphasizes humanity's common interest in its past, and argues that cultural objects should be relatively free to circulate to inspire 'mutual respect and appreciation among nations." ${ }^{[44]} \mathrm{A}$ third view, which in end result supports cultural nationalism, emphasizes the importance of preserving as much information as possible about the site where cultural objects are discovered. Advanced especially by archaeologists, it "stresses the importance of preserving objects [in their original contexts] [...] to maximize the information about the human past that can be derived from them." ${ }^{445]}$

There is no doubt today that in debates on this subject at the United Nations, or among art historians and archaeologists, the national cultural property doctrine is in the ascendant. Paul M. Bator has elucidated the doctrine as it applies to art: "The claims [...] for preserving the national patrimony [...] rest on the premise that art is special. [...] The art of a society is both a manifestation and a mirror of its culture." ${ }^{[461}$ Claire L. Lyons added the concept of "symbolic capital" to help articulate the underlying notions of cultural heritage and nationalism. "Cultural heritage [...] is central to a sense of purpose and place in the world [...] The idea of 'symbolic capital' can be used to encompass [the] many manifestations of [nationalism]." ${ }^{[4]}$ Karen Warren has referred to the "vital issue" raised by "those aspects of a country which are of special historical, ethnic, religious, or other cultural significance and which are unique in exemplifying and transmitting a country's culture." Cultural nationalism "assumes that countries have a legitimate claim to preserve [...] those aspects of their culture that represent their national identities." ${ }^{[48]}$ 
A multitude of other authors could be cited on cultural nationalism, ${ }^{[49]}$ but these quotations sum up what we see as the key points of agreement of the vast majority of commentators on this issue: Art is a special manifestation of culture. Art can be described and weighed in terms of its 'symbolic capital' for the cultural richness of a nation. The insistence of a country on the retention of the symbolic capital represented by its art is invariably legitimate.

The campaign by Ronald Lauder for the restitution of art to heirs of victims of the Holocaust challenges these assumptions so cherished today by many art historians and virtually all archaeologists. As noted earlier, in the discourse of Holocaust restitution, restrictions on export of art are called "pernicious." Negotiations with Jewish survivors of the Holocaust after World War II in which some export permits were granted in return for other works of art being donated to Austrian museums have been labelled "coercive." In the case of Maria Altmann, the press has applauded her for disavowing the 1948 "deal" made through her Austrian lawyer in order to recover five Klimts in 2006 now worth hundreds of millions of dollars. By way of contrast, in the discourse of cultural nationalism, the same governmental actions are invariably cited with approval. Export prohibitions are encouraged to protect a nation's patrimony and symbolic capital. ${ }^{[50]}$ Restrictions on property rights involving important works of art are considered normal; "inalienable patrimony" is a favoured term of proponents of the national cultural property doctrine. ${ }^{[51]}$ When a museum acquires an object whose return is demanded by its country of origin, the discourse of cultural nationalism tends to describe the museum's method of acquisition as "illegal" and characterizes the object as "robbed", irrespective of the specific circumstances of purchase. ${ }^{[52]}$ "Outright deals" are applauded as the most legitimate way for an individual collector to export or retain ownership of some of his or her great works of art as a quid pro quo for returning or leaving others to their country of origin. ${ }^{[53]}$ Can these two discourses be reconciled?

Representative James Leach, a member of the Congressional Arts Caucus, remarked at a 2006 Congressional hearing that "there is theft, and there is Holocaust theft. And to miss the importance of this would [...] not be good policy." ${ }^{[54]}$ Leach was certainly speaking as a politician, not as an academician, and he may have meant "good politics." In other words, he may have been asserting that, in the context of American politics, there is only one side to the Holocaust restitution debate, the side of the Jewish claimants. Another possibility is that Leach was simply espousing Holocaust "exceptionalism", i.e., that rules or rationales that would normally apply

\section{[49]}

See, for example, GREENFIELD, Jeanette. The Return of Cultural Trea-sures. Cambridge: Cambridge University Press, 1996; RICHMAN, Jennifer R. and Marion P. FORSYTH (eds.). Legal Perspectives on Cultural Resources. Walnut Creek, CA: Altamira Press, 2004; and BARKAN, Elazar. *Amending Historical Injustices: The Restitution of Cultural Property, An Overview ". In. BARKAN AND BUSH, op. cit, p. 16-41. Elazar Barkan promotes the return of antiquities to Greece and Italy; he has nothing to say of restitution to victims of the Holocaust. Although John $\mathrm{H}$. Merryman tends to be critical of cultural nationalism in his many books and articles, it is clear that he considers it to have won the allegiance of most writers on the subject. See MERRYMAN, John $\mathrm{H}$. Thinking about the Elgin Marbles, Critical Essays on Cultural Property, Art and Law. Hague: Kluwer, 2000, p. 34, where he notes that "the pressure for repatriation grows [to the country of the origin of works of art]."

[50]

See, for example, LYONS, op. cit, p. 123, where she excoriates the American Association of Museums for having criticized "foreign laws nationalizing cultural properties." Lyons laments "the wholesale demolition [caused by] centuries of unregulated trade."

[51]

See, for example, BARKAN AND BUSH, op. cit., p 17.

[52]

Barkan broadly describes museum acquisition practices as "immoral but time-honored" (op. cit., p. 31). 
[53]

See MERRYMAN's characterization of Norton Simon's 1974 agreement with India (op. cit,, p. 97).

[54]

Quoted in "National News". ArtNews, Summer 2006, p. 58.

[55]

Although national patrimony laws in countries such as

Austria and Mexico date from the early $20^{\text {th }}$ century, the academic doctrine of national cultural property seems to have received its impetus from the experience of World War II and its aftermath.

[56]

The Taliban's antipathy toward art objects went far beyond shooting up the giant Buddhas. (See RIDING, Alan. "Afghan Treasures, Hidden for Years, Shine Anew in Paris Exhibitionn. New York Times December 14, 2006, p B-5.

[57]

BAZYLER, op. cit, p. 202 become inapplicable in the context of the Holocaust. Arguments based on transcendental exceptions are like those from religious belief - they are difficult if not impossible to address on policy grounds. A related argument for the inapplicability of rules to protect national cultural property is that the Holocaust occurred in the context of World War II, and that Holocaust restitution is the most important restitution required as a remedy for the injustices and suffering caused by the war. However, making reference to the war raises other issues. There have been numerous wars and rebellions over the past decades, many associated with genocide or "ethnic cleansing," and if each such war is potential reason to disqualify the protection of national patrimony, then the doctrine in practice would become riddled with exceptions. More importantly, the reality of war, especially World War II, was itself the primary impetus for the development of the doctrine of national cultural property. ${ }^{[551}$ The Nazis seized and looted art throughout the countries conquered by Germany on a scale not seen since Napoleon. It was surely the experience of seeing national treasures "reallocated" throughout conquered Europe, primarily to Germany, that led the Austrians and other nations to insist so persistently (or "perniciously") on art export prohibitions in the late 1940 's in order to protect what was left of their national patrimony. In other words, the risks of war include the loss of national treasures, and the experience of war reminds nations to protect them.

In our opinion, because of these contradictions, the national cultural property doctrine cannot be reconciled with recent cases of restitution like that of Maria Altmann. Restitution of the Klimts should cause us to revisit assertions that have been ignored or undervalued by the proponents of cultural nationalism. A key lesson of Holocaust restitution is that collectors should have property rights in art vis-à-vis the nation state, including in most cases the right to export legitimately acquired art to their chosen home country. The experience of the Nazi period as well as the recent Taliban rule in Afghanistan demonstrates that national cultural policies on art can be entirely destructive. ${ }^{[66]}$ Today, the Nazi's campaign against "degenerate" art seems laughable, but in its day it led to clandestine sale or loss of hundreds of works of art in the name of national cultural policy. ${ }^{[6]}$ Individual collectors would have been much better stewards of the entire output of the German and Austrian expressionists than the German state proved to be. Unless supporters of cultural nationalism in art are willing to address Holocaust restitution and advance arguments that its tactics and results are wrong, then through their silence they have endorsed an exception that swallows up the rule. Apart from disavowing or seeking to curtail the 
current Holocaust restitution campaign, the only manner in which the two discourses can be reconciled is an admission by cultural nationalists that the policies of nation states can be misguided, that collectors, dealers, and museum directors often demonstrate superior wisdom as to what is best for art, and that individual and institutional owners should be able to make decisions on the disposition of their works of art that are at least the moral equivalent of the many "restrictive" policies of nation states. 
La restitution des œuvres d'art et des antiquités

[Traduit par Emma Healey]

La façon dont les musées gèrent les collections d'art fait aujourd'hui l'objet de plusieurs dissensions. Les défenseurs du patrimoine national et des biens culture/s soutiennent que le concept de musée universel, incarné par le British Museum et le Metropolitan Museum of Art de New York, est un exemple désuet de la pensée colonialiste et impérialiste. Au lieu de réunir les œuvres d'art des quatre coins du monde pour les étudier et les exposer dans les grands musées des pays développés, il faudrait plutôt les rapatrier dans leur pays respectif, qui sont souvent des pays sous-développés, où elles sont essentielles à l'expression et à la célébration de l'identité nationale de l'artiste. Les œurres créées dans un autre pays - telle la statue grecque exhumée dans le sud de l'Italie - ou dans une société disparue depuis longtemps - comme celles provenant de la Grèce antique ou des civilisations égyptienne et péruvienne - font également l'objet de réclamations.

Tandis que l'élaboration de ces pratiques envers les biens culturels compte de plus en plus d'adeptes, on note également un renouveau de l'intérêt porté à la restitution des œuvres d'art extorquées au cours de la Shoah. Puisque la plus grande partie des victimes dont les œuvres d'art ont été pillées par les nazis sont pour la plupart décédées, les revendications sont souvent faites par leurs descendants/ héritiers directs ou éloignés, nés dans les pays où leurs parents juifs se sont réfugiés. Les demandes de restitution tout comme celles de rapatriement sont assujetties aux lois sur le patrimoine national, mais pour des raisons différentes. Dans les cas où une nation cherche à rapatrier les œuvres d'art ou les antiquités envoyées à l'étranger clandestinement, la réclamation doit s'appuyer sur une réglementation nationale stricte qui établit clairement l'illégalité de ces exportations. Inversement, les réclamations concernant les œuvres extorquées au cours de la Shoah doivent surmonter l'obstacle juridique éventuel prescrivant l'exportation de l'œuvre d'art en question vers le pays de résidence du demandeur, puisqu'elle fait partie du patrimoine du pays dans lequel elle a été créée et où elle se trouve au moment de ladite réclamation. 
Il y a par ailleurs un point commun entre les litiges concernant les œuvres d'art de la Shoah et ceux sur les antiquités: l'identité des collectionneurs. En effet, en collectionnant des œuvres d'art et des antiquités, les musées tels que le Metropolitain Museum de New York sont la cible des réclamations visant ces deux types de litiges. Rappelons brièvement que la loi nationale des pays où ces œuvres ont été créées est un élément important dans le règlement des litiges. Cependant, la communauté scientifique traite ces deux types de litiges différemment et les journalistes les relatent de façon différente. Bien que les lois sur le patrimoine national et la doctrine sur les biens culturels nationaux qui les influencent soient essentielles à la réussite d'une réclamation sur la restitution des antiquités, elles sont considérées par la plupart des experts comme un empêchement injustifiable à la restitution des œurres de la Shoah.

Cet essai traite de cette contradiction évidente par une analyse de la restitution aux héritiers des victimes de la Shoah des œuvres saisies en Autriche sous le régime nazi. Même si l'accent est mis sur l'Autriche, les mêmes questions ont été soulevées dans presque tous les pays européens gouvernés ou occupés par les nazis. L'Autriche peut donc être à juste titre prise comme exemple pour illustrer les litiges concernant la restitution des œuvres de la Shoah. L'auteur décrit et analyse la doctrine sur les biens culturels nationaux, affirmant que les États-nations devraient avoir le droit moral suprême de déterminer quels objets d'art devraient rester à l'intérieur de leurs frontières. Il expose aussi comment cette doctrine va à l'encontre des conclusions de la campagne sur la restitution des œuvres sur la Shoah et démontre que les deux types de litiges ne peuvent être abordés de la même façon. Pour cette raison, la loi sur les biens culturels comporte une importante omission ébranlant ses suppositions fondamentales. 